\title{
The impact of health status and human capital formation on regional performance: Empirical evidence
}

\section{Mercedes Gumbau Albert}

Departamento de Análisis Económico,

Universidad de Valencia, Spain

\section{Correspondence}

Mercedes Gumbau Albert, Universidad de

Valencia, Departamento de Análisis

Económico, Edificio departamental oriental, Avda. de los Naranjos, s/n, 46022 Valencia,

Spain.

Email: mercedes.gumbau@uv.es

\begin{abstract}
The purpose of this paper is to analyse the impact of health on growth, assuming that it is a fundamental component of the human capital of a region along with education. Various measures of population health status are used, together with a health index generated by principal component analysis. Potential endogeneity between health and growth is controlled for using instrumental variable regressions and dynamic panel data. The results show a positive effect of a change in health status on regional output and a negative effect of proxy variables for health limitations on regional performance. This corroborates the importance of investing in health along with education with the aim of improving not only the well-being of individuals but the human capital and growth of a region.
\end{abstract}

\section{KEYWORDS}

education, health, human capital, regional economic performance

\section{1 | INTRODUCTION}

Economic growth has generated larger volumes of goods and services in many economies. This phenomenon arises from the accumulation of more and better technology and inputs like human capital. Although some studies proxy human capital with a measure of the educational level of individuals (De la Fuente \& Doménech, 2006; Lucas, 1988; Mankiw, Romer, \& Weil, 1992; Riley, 2012), others acknowledge that the role of education is overestimated if the influence of other dimensions of human capital, such as health, is not included (Bloom, Canning, \& Sevilla, 2004; Grossman, 2000; Lopez-Casanovas, Rivera, \& Currais, 2005). 
The introduction of health as a component of human capital is justified considering, according to Bloom et al. (2004, p. 1), that "healthier workers are physically and mentally more energetic and robust," which translates into higher productivity and higher wages. They are expected to perform better and are also less likely to take time off work due to illness or disability. Similarly, Strauss and Thomas (1998) report studies that have shown how health disorders substantially reduce hourly wages, especially in developing countries, where the proportion of the workforce engaged in manual labour is higher than in developed countries. And the same result is pointed by Cai, Mavromaras, and Oguzoglu (2014) who find that lower health status results in fewer working hours. More recently, Evans (2018) defines health as a foundational investment in a country's human capital because investing in health builds a productive workforce that transmits gains over generations and the World Bank Human Capital Index, described by Kraay (2018), measures the amount of human capital that a child born today can expect to attain by age 18, given the health and education that prevail in the country. O'Mahony and Samek (2019) recognize that health status is embodied in people and so should focus on the notion of human capital and Samek et al. (2019) view health as an investment good, which has the ability to improve individual well-being and, at the same time, increases time that people can allocate to work and, therefore, wealth.

Therefore the main hypothesis of the paper is that considering health is important in order to assess a region's progress and both factors, education and health, are relevant and complementary in the process of human capital accumulation. Following Becker (2007), human capital is not only defined as human skills, the stock of knowledge or intellectual capital, but is made up of education and health, variables that effectively reduce poverty through economic growth. And authors as O'Mahony and Samek (2019) acknowledge that health plays a significant role in generating human capital but the existing measures of human capital stocks do not adequately account for health status. However, a good measure of human capital is high on the policy agenda given its importance as a driver of economic growth. Based on the foregoing, the present study aims to use different measures of health that represent different aspects of health status and analyse the impact of health on growth of the Spanish regions, assuming that health is a fundamental component of the human capital of a region along with education. This helps to ensure that the contribution of one component of human capital is not overestimated by erroneously attributing to it the contributions of the omitted component.

The paper makes two innovative contributions to the literature. The first is to compare the effect of several different health measures on economic growth and is motivated by the lack of consensus about which measures of health status provide the most accurate results, suggesting the need for a comparison of different health measures or dimensions, which in turn can generate different economic effects. The second is the construction of a health index that combines the characteristics, relevant factors or possible proxies for health in a region. The novelty of the research at this stage is the use of principle component analysis (PCA) for modelling a health index at regional level. The study also aims to contribute to existing empirical evidence focusing on a regional case study.

The empirical analysis uses fixed-effect panel data, instrumental variables and system generalized method of moments (GMM), combining equations in first differences and in levels. The study results highlight the importance of differentiating between the health and education components of human capital, since they both have positive and significant effects on regional growth.

The paper is structured as follows. Section 2 presents a review of the literature and discusses the relationship between human capital and economic growth, distinguishing between education and health components. Section 3 describes the theoretical model analysed and the data used. In section 4 we empirically analyse the impact of the various dimensions of human capital on sectoral growth in the Spanish regions during the period 2004-2016. Finally, the main conclusions are presented in section 5 .

\section{2 | LITERATURE REVIEW}

Many articles have followed on the human capital dimensions of education and training, however, there have been many fewer discussions of health as human capital (Becker, 2007). More precisely, most of the economics literature 
on health discusses ways to improve the delivery of health care services forgetting that health status is embodied in people and, therefore, should also focus on the notion of human capital that, in turn, generates growth. This section reviews many of the theoretical and empirical models that have been developed in the literature to incorporate the impact of health, measured in different ways, on economic growth but is not an exhaustive survey like Monterubbianesi (2014), Monterubbianesi, Grandes, and Dabús (2017) or Bloom, Canning, Kotschy, Prettner, and Schunemann (2019). These revised models use and highlight different health measures, others highlight the complementarity in linking health to education and other types of human capital investments, and the vast majority support that fighting different diseases and increasing survival contributes to economic progress.

The relationship between health and economic growth varies depending on the dimension of health examined or the methodology used. Based on the theory of economic growth and expanding some of the existing models to incorporate health, Ehrlich and Lui (1991) used adult life expectancy as a proxy for health, whereas Kalemli-Ozcan, Ryder, and Weil (2000) reflect health through life expectancy at birth. Although these studies use different measures, both find that higher health status is associated with higher education levels or investment in human capital, which leads to enhanced economic performance. Using growth accounting as a tool, Bloom and Canning (2003) also hold that health as a factor of human capital has a positive impact on income. Therefore, improvements in the population's health reduce poverty in a country or region, thus justifying investment in health. In a similar vein, Howitt (2005) applies the Schumpeterian growth theory and proposes a production function to analyse the impact of improvements in the health and skills of a country's population on economic growth. His conclusions support the arguments of authors such as Barro (1996) by demonstrating that healthier workers are more productive. In turn, these more productive workers generate higher revenues ready to finance investments in technology or improve the level of skills, creativity and learning capacity in society as a whole, thus generating greater economic growth. The same author suggests that initial health status, measured by life expectancy or analogous aggregate indicators, seems to be an even better predictor of subsequent economic growth than initial education. Along the same lines, Gupta and Barman (2010) develop and endogenous growth model and also use the productivity argument by introducing health capital as an input in the production function.

Focusing on the link between the time horizon of life and the rate of economic growth, authors such as Aisa and Pueyo (2006) and Osag and Sarkar (2008) associate increased public spending with reduced lifetime uncertainty and the depreciation of human capital, showing that increased longevity leads to an increase in the savings rates and in returns on investments in physical and human capital and, therefore, on the economic growth rate. For their part, Ehrlich and Yin (2013) propose an overlappinggenerations human-capital-based endogenous-growth model that differentiates between the two key components of human capital: namely, education or knowledge capital, which acts as a driver of per capita income growth; and health capital, which is captured by probabilities of survival and health maintenance, and serves to facilitate the formation of knowledge capital. Given the characteristics of these factors, these authors consider investment in protecting the lives of children to be essential as a direct determinant of the long-term economic growth rate, since this investment is vital to safeguard the return on investment in education, and by extension, the development and growth of knowledge capital. Finally, Barro (2013) proposes an extension of the neoclassical model to study the interaction or joint determination between health and growth. His model captures a direct effect of health on productivity and an indirect effect due to the reduction in the depreciation rate of human capital (both education and health) brought about by lower illness and mortality rates. Through this channel, an increase in health status stimulates the demand for human capital, thus generating a positive effect on productivity.

With different samples according to the degree of development of the countries, we can identify channels of transmission from health to growth. On the one side, restricting attention to OECD countries, Aghion, Philippe, Howitt, and Murtion (2011) identify three arguments to affirm that health, measured by life expectancy, matters for growth. The first associates greater life expectancy with higher domestic and national savings, leading to increased capital accumulation, which in turn generates new and enhanced economic growth. Second, higher life expectancy leads to higher human capital formation and growth because improvements in health incentivize interest in 
schooling, whose costs can be amortized over a longer period in employment. Third, as Nweze (2015) also argues, better health could imply higher productivity, more creativity and better adaptation to technologies. Healthier people are better workers. They can work harder and longer, and also think more clearly. On the other side, Nweze (2015) analyses the point of view of underdeveloped countries affirming that healthier students also have lower absenteeism and higher cognitive functioning, and thus receive a better education for a given level of schooling. In addition, low child mortality may lead to a lower fertility rate; in consequence, population growth is slower, which may bring about an increase in GDP per capita.

There are, however, other channels through which health affects economic growth in developed countries. For example, in simulations for the US, Mierau and Turnovsky (2014) hold that rising life expectancy affects long-term growth positively due to higher aggregate savings resulting from longevity, and knowledge spillovers imply that aggregate returns to capital accumulation are non-diminishing. Capital accumulation on its own can therefore sustain economic growth in the long run. Focusing in particular on developed countries like Canada, France, Germany, Italy, Japan, the United Kingdom and the United States and using historical data for more than two centuries that are constructed as a population-weighted average of the individual countries' time series, Strulik, Prettner, and Prskawetz (2013) also argue that human capital has two dimensions--education and the stock of health--and note that it is this aggregate stock of human capital rather than the size of the workforce allocated to R\&D that matters for long-run economic growth. Similarly, Baldanzi, Buccinna, and Prettner (2017) show another path-way by which health has the potential to impact on long-run economic growth in modern knowledge-based economies that have already experienced the demographic transition in the past. They develop a model in which education and health are endogenously determined by investments made by parents. They conclude that long-run economic growth increases with health investments, and the reason for this is the complementarity between health and education, which is a crucial factor in raising levels of human capital, the key input in the R\&D sector.

In developed countries, the impact of health on growth is also transmitted through changes in labour supply. The empirical evidence for industrialized countries shows that increasing longevity and good health, with correspondingly longer working lives, could help to prevent increased dependency in old age (e.g., Loichinger \& Weber, 2016 for Europe's case). That is, an increase in longevity should lead to an increase in labour supply and savings in retirement expenditures (e.g., Chen \& Lau, 2016; Prettner \& Canning, 2014). In turn, Kuhn and Prettner (2016) argue that health-related increases in the working life have surprisingly ambiguous effects on economic growth: on the hand, health improvements increase longevity and reduce mortality, driving participation in the labour market and reducing retirement savings. R\&D activity and economic growth are then slowed down by the consequent rise in interest rates. On the other hand, these authors also state that as long as the expansion of health care increases capital accumulation, this stimulates factor substitution toward capital in the manufacturing sector and serves to strengthen R\&D activity, which enhances productivity.

At this point we have identified various channels through which health affects growth and is easy to see that differences exist between the economic effects of health interventions in less developed countries and developed countries. Bloom et al. (2019) summarize these differences, thus, in less developed countries, poor health often reduces labour force participation, particularly among women, and deters investments in education such that fertility stays high and the economy remains stagnated. By contrast, in more developed countries, health investments primarily increase longevity, which may not significantly affect labour force participation and workforce productivity.

At the empirical level, growth accounting models also measure how health status, as a factor of production, contributes to the rate of economic growth finding different effects according to the health measures used. Bloom et al. (2004) demonstrate for developing and industrial countries that health has a significant impact on economic performance using life expectancy data as a proxy for health: an increase of life expectancy of five years was associated with a growth rate up to 0.6 percentage points higher than otherwise. Heshmati (2001) and Rivera and Currais (2004) also found a robust and significant effect on economic growth using health care expenditure, McDonald and Roberts (2005) using health capital stocks, and Bloom and Canning (2005) with the adult survival rate. Hansen (2013) quantifies the effect of increased life expectancy and improved infant health on rising human capital 
investment as follows: one additional year of life expectancy increases years of schooling by 0.17 years, which in turn stimulates economic growth.

Also different effects according to the status of economic development exist. Weil (2007) asks how much of the gap in income between rich and poor countries is accounted for by differences in health, concluding that if these differences among countries--measured by the adult survival rate--were eliminated, the variance of log GDP per worker would fall by 9.9\%. Quamrul, Lester, and Weil (2009) also studied whether exogenous health improvements in developing countries, such as life expectancy and the eradication of certain diseases, expand national income. These authors determined that the beneficial effects of improved health can only be appreciated after a fairly long period of time and that the same holds for the effect of this improvement on a country's income. They also analyse the effect of eradicating particular diseases concluding that even when complete eradication is achieved, the impact on income per capita is relatively small. Moreover, these relatively small effects vary by disease, such that eradicating illnesses that affect prime-age workers increases income, whereas eliminating diseases that affect mainly young children has no impact on income. Because these gains are surprisingly small, the authors recognize that they have a greater effect on welfare than on the economy.

More recently, Desbordes (2011) finds support for a U-shaped relationship between GDP per capita and life expectancy, whereas Kumar and Kober (2012) used a large sample of 97 countries to empirically study the way health, education, and urbanization impact their total factor productivity. These authors report that levels of urbanization and health capital, proxied by life expectancy, infant mortality rate and the risk of malaria, have a significant impact on total factor productivity, but the effect of education is not significant. Coefficients of health and urbanization indicators remain highly significant even after controlling for endogeneity. Luca et al. (2014) consider that even small improvements in the working age population can have a major economic impact in developing countries. However, authors such as Hall and Jones (2007), Weil (2014), Jones (2016), Jones and Klenow (2016) and Kuhn and Prettner (2016) argue that in the most developed countries, the effects of health on economic growth are likely to be less important, and even report that the high costs of advanced health care systems can be a deterrent to growth. Similarly, Hansen and Lønstrup (2015) find that during the twentieth century increased life expectancy stimulated population growth but reduced GDP per capita. In addition, these authors demonstrate a negative relationship between initial level of life expectancy and the subsequent growth rate of GDP per capita. In the same vein, Cervellati and Sunde $(2011,2015)$ show that improved longevity stimulates investment in education and economic growth if countries have already experienced a demographic shift from high to low rates of fertility and mortality; when this is not the case, the effect of improved longevity is manifested in greater population growth only.

Along this line, other regional studies have also corroborated and provide empirical evidence on the appearance of a gap in income and growth when health declines. Thus, Oliva-Moreno (2012) sustain that the loss in labour productivity due to accidents and health problems was estimated to a figure equivalent to nearly $4.2 \%$ of the GDP of Spain in 2005 and Blázquez-Fernández, Cantarero-Prieto, Perez-Gonzalez, and Llorca-Díaz (2015) suggested that a greater risk of early-life death is associated with higher levels of fertility and lower investment in physical and human capital that, in turn, impact negatively in income. Recently, Lenhart (2019) examines data from the British Household Panel Survey to test how sudden health shocks affect labour and household income, employment status, and hours worked. By estimating propensity score matching difference-in-differences models, the study shows that sudden health declines lead to significant and persistent reductions in earnings that are strongest for individuals experiencing severe health shocks, males, individuals with higher education and those working in managerial jobs. O'Mahony and Samek (2019) also show an application for the UK in 2014 and quantify that overall the UK economy would have had about $11 \%$ more human capital if those in ill health were in good health.

In light of the results from most of the studies analysed in this literature review, we can conclude that health improvements can be a fundamental factor for economic development. However, there is no firm consensus in the literature on the impact value and different results are obtained according to the health measure used and the methodology applied. Besides, highlighting the role of infectious diseases, which continue to plague many developing countries and even have attacked the developed countries is important considering that they can trap economies. 
There should be consensus in highlighting the importance of health and the urgency of eradicating epidemic crises to allow the population to accumulate human capital. For all these reasons, further empirical research is needed.

\section{3 | THE MODEL AND THE MEASUREMENT OF THE VARIABLES}

The main objective of this study is to include health along with education in a well-specified aggregate production function to quantify the effect of health on economic growth and at the same time evaluate the impact of differences related to education. Although most studies limit human capital to education, this underestimates the impact of human capital or overestimates the role of education. In other words, the multidimensional nature of human capital calls for a model of growth that covers its main components: health capital $(T)$ and education capital (E). This paper follows the macro-based approach of Weil (2001), Bloom and Canning (2005) and Bloom et al. (2019) and estimates a generalized aggregate production function that decomposes output into its components:

$$
Y_{i t}=A_{i 0} K_{i t}{ }^{\alpha} H_{i t}{ }^{\beta},
$$

where $Y_{i t}$ is the private production of region $i$ in year $t, A_{i 0}$ is the initial level of efficiency or productivity for each region, $K_{i t}$ is the physical capital of region $i$ in year $t$, and $H_{i t}$ is the human capital of region $i$ in year $t$. Human capital can be decomposed into the employment of region $i$ in year $t$, denoted by $\mathrm{L}_{i}$, and its average human capital, such that:

$$
\mathrm{H}_{\text {it }}=\mathrm{L}_{\mathrm{it}} v_{\mathrm{it}} \text {, }
$$

where

$$
v_{\text {it }}=\mathrm{e}^{\phi E E i t+\phi T T i t,}
$$

and $E$ represents education of region $i$ in year $t$ and $T$ represents health of region $i$ in year $t$. Taking logarithms we can estimate the following equation:

$$
\operatorname{LnY}_{i t}=\operatorname{LnA}_{i 0}+\alpha \operatorname{LnK}_{i t}+\beta \operatorname{Ln}_{i t}+\phi_{E} \operatorname{LnE}_{i t}+\phi_{T} \operatorname{LnT}_{i t}+u_{i t} .
$$

Equation 4 will be estimated to highlight the importance of human capital in its two main dimensions--health and education intensity--to regional growth. For this purpose, we construct a balanced panel of the seventeen autonomous communities of Spain for the period 2004-2016. This is the period for which the variables used in the analysis are available.

The following variables and statistical sources are used in Table $1:^{1}$ production of each region, measured by gross value added, obtained from the Spanish Regional Accounts of the National Institute of Statistics (INE). This variable is expressed in euros at 2010 values. Number of employees $(L)$ is obtained, as above, from the INE Regional Accounts. Private capital $(K)$ is obtained from estimates by the Instituto Valenciano de Investigaciones Económicas (IVIE) for the BBVA Foundation.

To measure the variable Education at regional level the paper uses the percentage of people in work who have completed the following education: university degree or bachelor's degree or certificate of higher education. The ability of regions to develop higher quality products, innovate, undertake and orientate production towards more dynamic markets and sectors is closely related to their endowment of human capital that, in turn, generates growth

${ }^{1}$ Table 1 provides the name of the variables, a short description and sources. 
TABLE 1 Variables and data source

\begin{tabular}{|ll|l}
\hline Variable & Definition & Data \\
\hline Y & gross value added & Source \\
\hline L & number of employees & INE \\
\hline K & private capital & INE \\
\hline Education & percentage of people in work who have completed University degree, Bachelors degree or & IVIE \\
\hline Education & Certificate of Higher Education & IVIE \\
\hline++ & people in work who have completed University degree & IVIE \\
\hline EVAN & life expectancy at birth & INE \\
\hline EV65 & life expectancy at age 65 & INE \\
\hline MB & percentage of individuals reporting a favourable state of health & INE \\
\hline LIMGRAL & percentage of people with long-term health problems & INE \\
\hline
\end{tabular}

in regions. Following the work of Serrano (1996) and Serrano and Soler (2015), it is assumed that human capital has a direct relationship with the years of schooling carried out by each individual, but knowledge can also be acquired through work experience. Together they provide a very useful measure of people's ability to produce market-valued goods and services. To represent both aspects, the relevant variable, which is the one used in this paper, is the employed population that reaches the educational levels provided by higher education, considering knowledge as well as skills with a more practical approach and closer to companies. Alternatively, a more restrictive version of the variable, called (Education ++), will also be used, which includes only the university degree. The latter provides information of the highest level of knowledge and skilled workers. In both variables (Education and Education++), individuals have completed more than 14 years of schooling. These statistics are also provided by the IVIE. ${ }^{2}$

Finally, the INE provides the regionalized information on health indicators used in the analysis. Compared to other forms of human capital, health status is particularly difficult to measure because it can be proxied by various indicators. For this reason we use five indicators that gather aspects related both to survival and quality of life of the population. Related to the survival rate, the first indicator we use is life expectancy at birth (EVAN), or the number of years a newborn would live if the mortality patterns current at the moment of birth did not change during his or her lifetime. This is one of the most commonly used indicators in the literature because greater life expectancy is fully correlated with a higher level of health in a country. Secondly, we use life expectancy at age 65 (EV65), or the number of years a 65 -year-old person would live if the mortality patterns for that year did not change. This indicator acts as a proxy for the health of the workforce (see Bloom et al., 2019), and its application appears to be particularly appropriate in developed countries where life expectancy for adults has changed radically in recent decades, and which tend to have larger workforces with higher levels of experience.

Health status can also be proxied by indicators that reflect individuals' quality of life or what they perceive their own general state of health to be, or by periods of time during which illness prevented them from working, among others. In this study we use two indicators taken from information provided by the INE: MB, the percentage of individuals reporting a favourable state of health, and LIMGRAL, the percentage of people with long-term health problems that prevent them from working on a regular basis.

Finally, Table 2 presents the principal component analysis (PCA) from which we obtain a combined measure for regional health by reducing the initial variables into an individual variable that preserves as much of the initial information and variability as possible. More precisely, the table shows that the main two components of the PCA explain

${ }^{2}$ A more detailed analysis of the human capital statistics for the Spanish case, incorporated into the OECD statistics, can be found in Mas, Pérez, Uriel, Serrano, and Soler (2002a, 2002b), Serrano and Pastor (2002), Maudos, Pastor, and Serrano (2003) and Pastor, Peraita, Serrano, and Soler (2018). 
TAB LE 2 Principal component analysis: health index

\begin{tabular}{|lcccc|} 
Component & Eigenvalue & Difference & Proportion & Cumulative \\
\hline Comp1 & 2.01321 & 0.74417 & 0.5033 & 0.5033 \\
\hline Comp2 & 1.26903 & 0.57263 & 0.3173 & 0.8206 \\
\hline Comp3 & 0.69639 & 0.48558 & 0.1741 & 0.9947 \\
\hline Comp4 & 0.21361 & 0.67503 & 0.0053 & 1.0000 \\
\hline & PC1 & PC2 & PC3 & PC4 \\
\hline EVAN & 0.6951 & -0.0702 & 0.1231 & -0.7049 \\
\hline MB & 0.0291 & 0.7313 & 0.6774 & 0.0742 \\
\hline EV65 & 0.6895 & -0.1533 & 0.0586 & 0.7054 \\
\hline LIMGRAL & 0.2015 & 0.6610 & -0.7228 & 0.0067 \\
\hline
\end{tabular}

$82 \%$ of the total variance, with the first component offering the greatest amount of the explained variance with a total of $50 \%$, and the second $31 \%$. The third offers $17 \%$ and the rest $0.5 \%$. The transformed variables are independent of each other and lack collinearity between them. Therefore, with these variables an index is created that is a linear combination of those described above. In other words, this is a health index that gathers the different components of health (HEIN). Such a measure allows us to deal with the problem of multicollinearity among the initial variables if they were included in a regression model. PCA is therefore recommended because is considered among the best methods to identify the unobservable, "latent" factors that underlie or "explain" a set of observed variables (Coste, Bouee, Ecosse, Leplege, \& Pouchot, 2005; Friesen, Seliske, \& Papadopoulos, 2016).

\section{$4 \quad$ RESULTS}

Table 3 shows the descriptive statistics while Table 4 shows the differences in mean values between regions in the period 2004-2016. It is observed that these differences are mainly marked in Education++, that is, the percentage of people in work who have completed a university degree (Madrid is 2,5 times higher than the Balearic Islands). On the other hand, the differences are smaller in life expectancy at birth, since in the region of Murcia (the highest life expectancy) it is only $1.5 \%$ higher than the national average and in Andalusia (the lowest life expectancy) it is $1.7 \%$ lower than the mean of Spain.

To highlight the impact of health on economic growth, Equation (4) was estimated for the seventeen Spanish regions in the period 2004-2016. The estimation was first made with panel data techniques, which take into account the possible unobservable characteristics of each individual that are constant over time by introducing individual regional effects. The results are presented in Table 5. Despite its advantages, this technique also has the drawback that it cannot adequately solve the problem of endogeneity, which must be addressed in this study. The question arises of whether the regions that have better health on average are more productive, or whether regions are able to improve their health factor because of higher income. Thus, to correct the bias that arises if this situation is ignored,

TABLE 3 Descriptive statistics

\begin{tabular}{|llllllrl|} 
& Education & Education++ & EVAN & EV65 & MB & LIMGRAL \\
\hline Mean Spain & 36.55081 & 14.39305 & 81.84932 & 20.37216 & 70.58326 & 6.112217 \\
\hline Max & 55.26528 & 31.43296 & 84.6 & 22.22373 & 81.5 & 14.6 \\
\hline Min & 19.73834 & 7.189331 & 78.8 & 18.03282 & 54.2 & 2.2 & 2.26312 \\
\hline Std. Dev & 7.495281 & 4.401805 & 1.174371 & 0.8215579 & 5.249471 & 2.2 \\
\hline
\end{tabular}




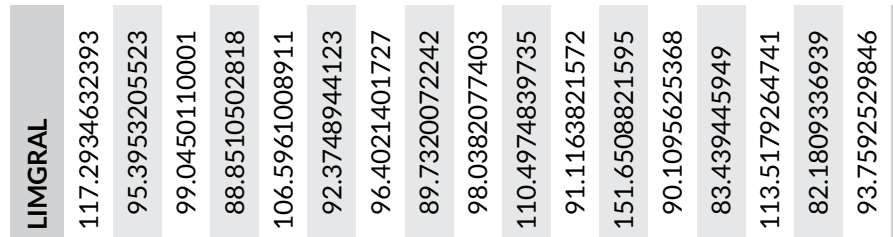

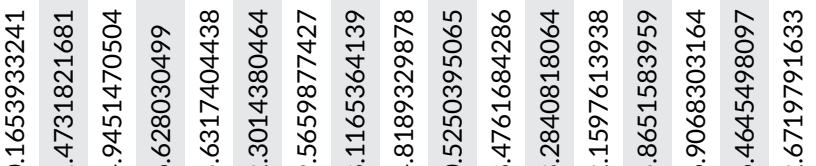

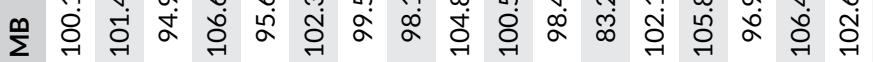

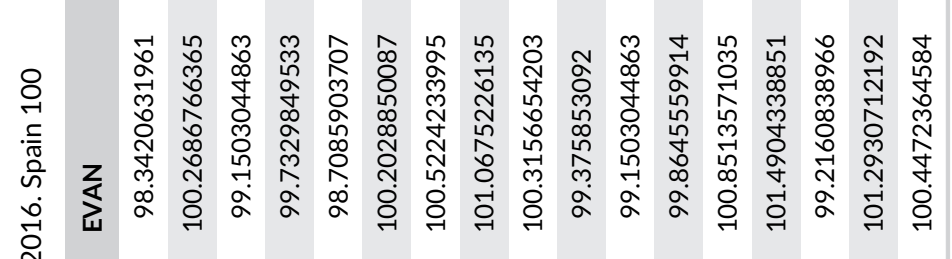

¿ั่

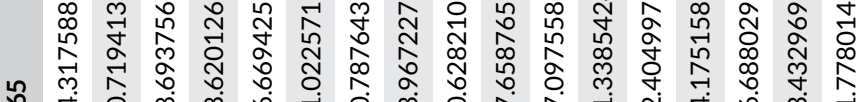

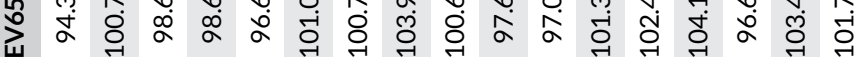

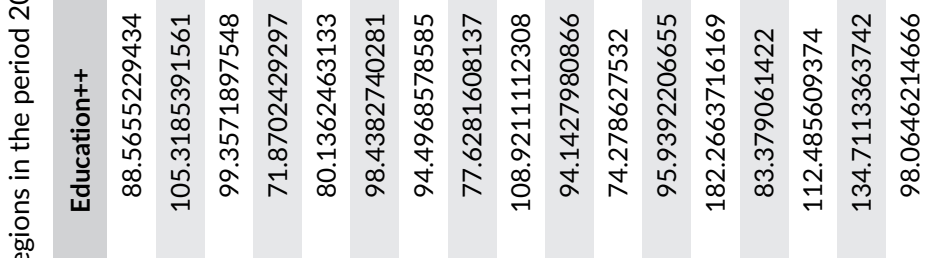

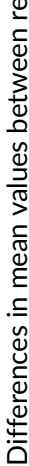

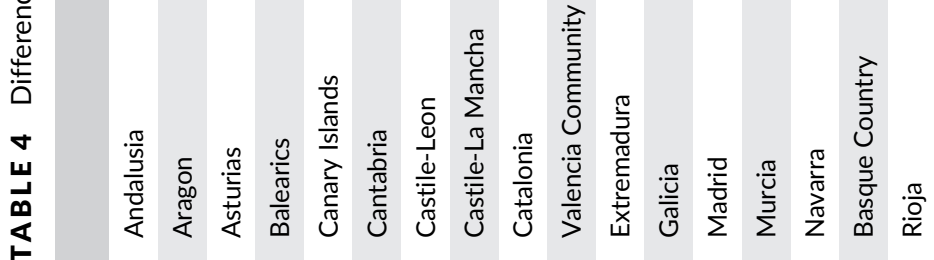




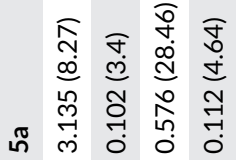

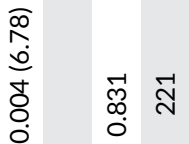

ช

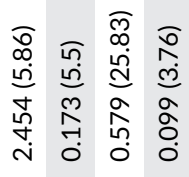

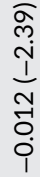

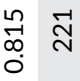

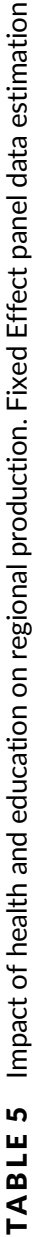

ฝิ

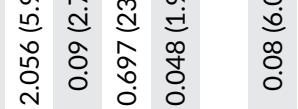

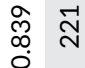

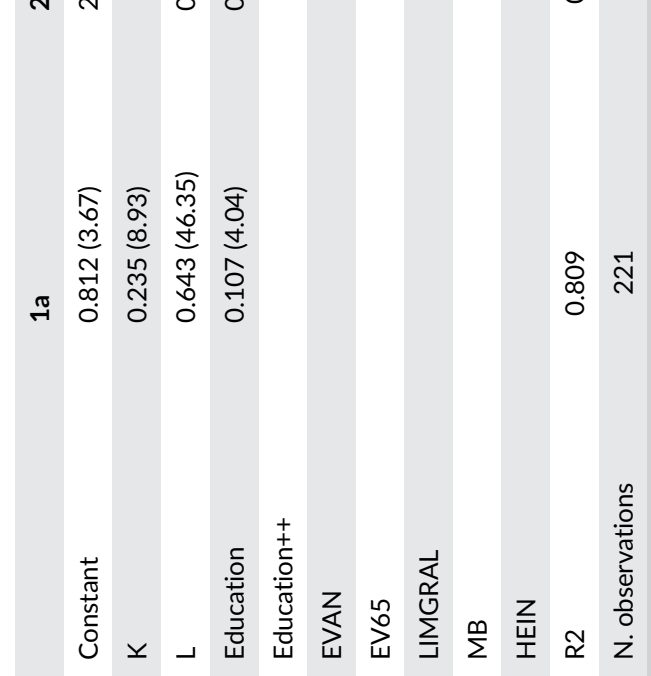




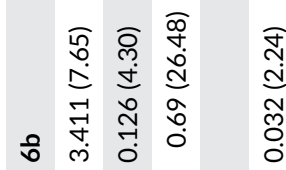

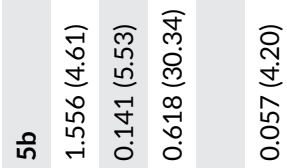

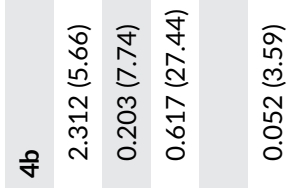

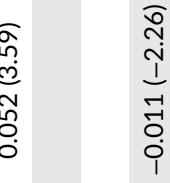

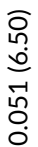

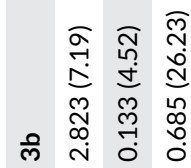

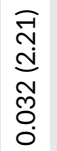

\begin{tabular}{l}
$\pi$ \\
0 \\
in \\
\multirow{2}{*}{} \\
0 \\
0 \\
0
\end{tabular}

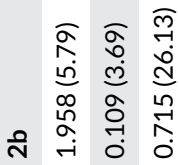

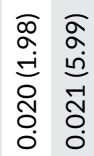

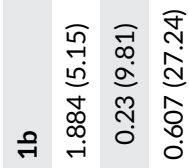

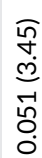

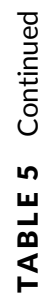

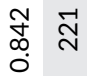

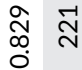

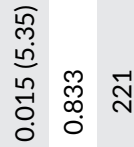

$\underset{\substack{0 \\ 0}}{\stackrel{N}{*}}$

$\underset{\substack{\infty \\ 0}}{\infty}$

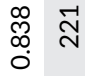

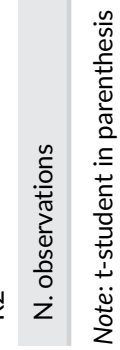


instrumental variables are used in the estimations of Tables 6 and 7. A comparison with these two tables will increase the robustness of the results.

Specifically, Table 6 performs the estimation with fixed effects but using instrumental variables. To do this, lags of the variable to be instrumentalized are used. The particular feature of these lags is that they are correlated with the explanatory variables of the model but not with the error term, conditions that a variable must meet for it to be instrumental.

Arellano and Bond (1991) constructed an estimator based on a generalized method of moments (GMM), which uses instrumental variables based on lags in the endogenous and predetermined variable(s) and differences of all exogenous variables in the model, and that is particularly suited for panels with several individuals and few time periods, as in the present case. Table displays the results yielded by the system GMM estimator that estimates the relationship between the dependent variable and the explanatory variables using the information from both

TAB LE 6 Impact of health and education on regional production. FE-IV estimation

\begin{tabular}{|c|c|c|c|c|c|}
\hline & 1 & 2 & 3 & 4 & 5 \\
\hline Constant & $1.685(4.04)$ & $2.800(6.31)$ & $2.130(4.31)$ & $2.594(5.58)$ & $3.182(6.29)$ \\
\hline K & $0.104(3.12)$ & $0.107(3.40)$ & $0.182(5.54)$ & $0.124(3.75)$ & $0.117(3.53)$ \\
\hline $\mathrm{L}$ & $0.714(23.96)$ & $0.589(28.68)$ & $0.595(26.14)$ & $0.677(24.81)$ & 0.687 (24.89) \\
\hline Education & 0.049 (1.98) & $0.126(4.81)$ & $0.105(3.66)$ & $0.064(2.29)$ & $0.062(2.28)$ \\
\hline EVAN & $0.029(5.97)$ & & & & \\
\hline MB & & 0.004 (6.79) & & & \\
\hline LIMGRAL & & & $-0.0124(-2.54)$ & & \\
\hline EV65 & & & & $0.024(5.26)$ & \\
\hline HEIN & & & & & $0.015(5.62)$ \\
\hline $\mathrm{R}^{2}$ & 0.827 & 0.835 & 0.800 & 0.820 & 0.824 \\
\hline N.observations & 204 & 204 & 204 & 204 & 204 \\
\hline
\end{tabular}

Note: t-student in parenthesis.

TABLE 7 Impact of health and education on regional production. GMM-IV estimation

\begin{tabular}{|llllll|}
\hline & 1 & 2 & 3 & 4 & 5 \\
\hline Constant & $0.266(0.60)$ & $1.493(3.54)$ & $0.764(1.65)$ & $1.825(6.63)$ & $0.133(0.31)$ \\
\hline K & $0.187(4.47)$ & $0.162(4.51)$ & $0.224(5.47)$ & $0.082(2.65)$ & $0.260(8.11)$ \\
\hline L & $0.677(44.12)$ & $0.657(42.67)$ & $0.618(26.63)$ & $0.599(41.98)$ & $0.641(50.01)$ \\
\hline Education & $0.149(3.57)$ & $0.125(3.24)$ & $0.141(3.24)$ & $0.238(7.75)$ & $0.126(5.38)$ \\
\hline EVAN & $0.008(7.40)$ & & & & $0.004(5.77)$ \\
\hline EV65 & & $0.015(8.61)$ & & & $0.71)$ \\
\hline LIMGRAL & & $-0.009(-2.88)$ & & 0.994 \\
\hline MB & & & & 0.994 & 0.013 \\
\hline HEIN & & 0.995 & 0.994 & 0.283 & 0.367 \\
\hline Sargan test (p value) & 0.995 & 0.029 & 0.118 & 0.062 & 221 \\
\hline AR(1) (p value) & 0.053 & 0.034 & 0.106 & 221 & \\
\hline AR(2) (p value) & 0.075 & 221 & 221 & & \\
\hline N.observations & 221 & & & & \\
\hline
\end{tabular}

Note: t-student in parenthesis. 
equations, in levels and in differences. First-order correlation must be present in this estimation, since otherwise it would be indicating that there are no dynamic effects and the GMM estimator would not be suitable. In addition, an important limitation of the estimator is that second-order autocorrelation cannot exist in the first differences of the errors. The results of the Arellano-Bond test presented in Table corroborate this fact; additionally, the Sargan test shows that the equations are correctly overidentified. The results no longer reject the null hypothesis that the overidentifying restrictions are valid.

The analysis of these tables reveals that the results of the estimations tend to coincide regardless of the estimator used confirming the robustness of the results. Thus, the results of the fixed-effect panel data estimation (Table 5) show that the capital and labour parameters are significant and the sum of these coefficients is close to one, which is consistent with constant returns to scale. Additionally, the first equation shows that when the proxy variables for health are not included, the estimate of the coefficient on schooling yields a social rate of return of $10 \%$. In the subsequent equations the variables proxying health are introduced and the main conclusion is that health has a statistically significant effect on economic growth regardless of how the health variable is measured. Both life expectancy at birth (EVAN) and life expectancy at age 65 (EV65) have a positive effect on economic growth in the regions. These results are similar to findings of other studies such as Bhargava, Jamison, Lau, and Murray (2001), Bloom et al. $(2004,2019)$ suggesting that a 1 year increase in life expectancy at birth leads to a rise in output of $8 \%$, and secondly, that an increase of 1 year in life expectancy at age 65 generates a $2 \%$ increase in output. The conclusion drawn from these results is that increasing health expenditure is justified not only because it improves the welfare of individuals, but also because worse health status in a region leads to lower life expectancy and is growth-reducing. Improvements in health may raise output through the accumulation of capital if life expectancy influences life cycle savings and capital accumulation. Similarly, improvements in health leads to higher work force productivity, and therefore, output. All these mechanisms allow regions to enhance growth (Bloom, Canning, \& Malaney, 2000) and become a source of competitiviness.

The results also show a significant positive impact on regional performance when we use the explanatory variable MB, a measure of individuals' perception of their own health; in contrast, a significant negative effect was found with the variable LIMGRAL, representing the health limitations reported by individuals. Both variables have the expected sign and are strongly significant according to the $t$ statistic provided by the table. The results show that the marginal effect on growth of a positive change in health status is $0.4 \%$, whereas a negative effect implies a fall in production of $1 \%$.

The construction of a health index such as the one proposed in this study enables the multidimensional nature of health to be included in the analysis, since in developed countries the impact of health is not only dependent on life expectancy but also on the specific health status of individuals at any given moment. When the regression includes this combined health index, which represents individuals' own perception of their health status, its effect is also positive and significant, although to a lesser degree, since the negative effect generated by health limitations is also taken into account.

Additionally, Table illustrates the results using a more restrictive measure of the human capital associated to schooling, that is, Education ++. When analysing the results, it can be observed how, in a systematic way, as expected (see Serrano, 1996; Serrano \& Soler, 2015), the estimated value of the coefficients of the human capital indicator decreases as the education qualification criterion becomes more demanding. However, in all cases, the sign and significance of the variables that define the regional health status are maintained.

The results presented in Tables 6 and 7 also lead to the same conclusions and suggest that when measured only by schooling of the workforce, the effect of human capital on regional performance is undervalued when the effect of proxy variables for health is omitted. Specifically, according to the study's findings, the effect of human capital measured by schooling of the workforce has no less impact or significance when the health variable is controlled for except for some specifications. This suggests that the two variables are capturing different effects of human capital, and that they both have positive effects on regional performance. In other words, Education is not capturing the effect of health on performance. 


\section{5 | CONCLUSIONS}

The objective of this paper is to obtain evidence of the effect of population health on economic growth. To this end, the population's health was considered as one of the main components of human capital, as well as the regional endowment of education. Estimations were performed using different measures of health, some of which have been used previously in the literature such as life expectancy at birth and adult life expectancy. However, this study also uses measures of individuals' perception of their own health and a mixed or multidimensional index that gathers different aspects of health, and is therefore a more complete and accurate health index.

These variables of human capital-education and health-have a positive and significant influence on regional performance, with the exception of the health limitations variable, which has a negative impact. For the estimates, panel data and instrumental variables have been used, which reduce the problems of endogeneity caused by introducing variables that represent health status in the regions. An estimator based on the GMM has also been constructed. The conclusion that health is an important determinant of regional growth is robust to using a variety of different health indicators, as well as to using alternative estimates of the return on health.

One of the main findings of this study is that the return rate on education does not capture the effect of health, and thus the estimation of the contribution of human capital on economic growth would be biased (underestimated) when health measures are omitted. Furthermore, we find that the impact of education on regional productivity is $10 \%$, whereas the impact of health on regional performance oscillates between $0.4 \%$ and $2 \%$ depending on the health measure considered. This result is important in that it can help to identify public policy measures that lead to an improvement in the conditions of both the education and health of individuals and, therefore, their productivity and income.

In summary, the results of the study show that the growth of the Spanish regions comes not only from the physical capital and labour endowments or from the educational level of the regions, but also from the health endowments. If human beings are one of the most important productive assets in the economy, the health service contributes to improving this asset. This result is of primary importance and has a number of consequences from the perspective of economic policy.

On the one hand, this result proves that there are compelling economic reasons to invest resources in creating a healthy workforce. If a person is unable to work for health reasons, is more likely to lose the job, which in turn reduces income, spending and savings. The question also arises as to whether it is beneficial to have public support for more universal health coverage. When public policies improve people's health, they also increase the benefits that a healthy environment generates for other people. Furthermore, regional growth also increases, leading to a higher standard of living among the population. On the other hand, having a powerful and competitive health system is not only an engine of well-being, but it is the best instrument to analyse and vmanage the potential risks of humanity. Investments in health care are a tool to minimize national risk. A greater investment in the required health system would have greatly minimized the current health crisis in the Spanish regions and, consequently, its serious economic effects. Decision-makers must consider the consequences of not investing in the health sector, which may become more expensive in the future. Fostering an adequate public health economy for the twenty-first century is not optional for the regions. Global economic dynamics and demographic factors require that all regions consider health as an investment, rather than an economic burden. Finally, investments in health can also reduce economic inequality. Especially if health care programmes are provided at an early age creating access to best opportunities and lifelong benefits. Not investing in health is unproductive and can generate huge costs, especially for the most disadvantaged, and these high costs can be a serious disadvantage for the new generations.

\section{ACKNOWLEDGEMENT}

The author gratefully acknowledges financial support from the Spanish Ministerio de Economía y Competitividad under the project ECO2017-84828-R (AEI/FEDER, UE). 


\section{ORCID}

Mercedes Gumbau Albert (1) https://orcid.org/0000-0002-9290-6971

\section{REFERENCES}

Aghion, M., Philippe, T., Howitt, P., \& Murtion, F. (2011). The relationship between health and growth: when Lucas meets Nelson-Phelps. Review of Economics and Institutions, 2(1), 1-24. https://doi.org/10.5202/rei.v2i1.22

Aísa, R., \& Pueyo, F. (2006). Government health spending and growth in a model of endogenous longevity. Economic Letters, 90(2), 249-253. https://doi.org/10.1016/j.econlet.2005.08.003

Arellano, M., Bond, S. (1991). Some tests of specification for panel data: Monte Carlo evidence and an application to employment equations. The Review of Economic Studies, 58(2), 277-297. https://doi.org/10.2307/2297968

Baldanzi, A., Buccinna, A., \& Prettner, K. (2017). Children's health, human capital accumulation and R\&D-based economic growth. Hohenheim Discussion Papers in Business, Economics and Social Sciences 01-2017, University of Hohenheim, Faculty of Business, Economics and Social Science.

Barro, R. (2013). Health and economic growth. Annals of Economics and Finance, 14-2(A), 305-342.

Barro, R. J. (1996). Determinants of economic growth: A cross-country empirical study. National Bureau of Economic Research Working Paper 5698.

Becker, G. S. (2007). Health as human capital: Synthesis and extensions. Oxford Economic Papers, 59(3), 379-410. https:// doi.org/10.1093/oep/gpm020

Bhargava, A., Jamison, D. T., Lau, L. J., \& Murray, C. J. (2001). Modeling the effects of health on economic growth. Journal of Health Economics, 20(3), 423-440. https://doi.org/10.1016/S0167-6296(01)00073-X

Blázquez-Fernández, C., Cantarero-Prieto, D., Perez-Gonzalez, P., \& Llorca-Díaz, J. (2015). Does health enhance economic growth? Evidence from Spain. Applied Economic Letters, 22(11), 860-864. https://doi.org/10.1080/13504851.2014.982851

Bloom, D., \& Canning, D. (2003). The health and poverty of nations: From theory to practice. Journal of Human Development, 4(1), 47-71. https://doi.org/10.1080/1464988032000051487

Bloom, D., \& Canning, D. (2005). Health and economic growth: Reconciling the micro and macro evidence. Center on Democracy, Development, and The Rule of Law. Stanford Institute on International Studies Working Paper 42.

Bloom, D., Canning, D., Kotschy, R., Prettner, K., \& Schunemann, J. (2019). Health and economic growth: Reconciling the micro and macro evidence e, NBER Working Paper 26003, National Bureau of Economic Research, Inc.

Bloom, D., Canning, D., \& Malaney, P. (2000). Population dynamics and economic growth in Asia. Population and Development Review, 26, 257-290. https://www.jstor.org/stable/3115219

Bloom, D., Canning, D., \& Sevilla, J. (2004). The effect of health on economic growth: A production function approach. World Development, 32(1), 1-13. https://doi.org/10.1016/j.worlddev.2003.07.002

Cai, L., Mavromaras, K., \& Oguzoglu, U. (2014). The effects of health status and health shocks on hours worked. Health Economics, 23(5), 516-528. https://doi.org/10.1002/hec.2931

Cervellati, M., \& Sunde, U. (2011). Life expectancy and economic growth: the role of the demographic transition. Journal of Economic Growth, 16(2), 99-133. https://www.jstor.org/stable/41486924, https://doi.org/10.1007/s10887-011-9065-2

Cervellati, M., \& Sunde, U. (2015). The effect of life expectancy on education and population dynamics. Empirical Economics, 48, 1445-1478. https://doi.org/10.1007/s00181-014-0830-x

Chen, Y., \& Lau S.-H. P. (2016). Mortality Decline, Retirement Age, and Aggregate Savings. Macroeconomic Dynamics, 20(3), 715-736. https://doi.org/10.1017/s136510051400056x

Coste, J., Bouee, S., Ecosse, E., Leplege, A., \& Pouchot, J. (2005). Methodological issues in determining the dimensionality of composite healthmeasures using principal component analysis: Case illustration and suggestionsfor practice. Quality of Life Research, 14, 641-654. https://doi.org/10.1007/s11136-004-1260-6

De la Fuente, A., \& Domenéch, A. (2006). Human capital in growth regressions: How much difference does data quality make? Journal of the European Economic Association, 4(1), 1-36. https://doi.org/10.1162/jeea.2006.4.1.1

Desbordes, R. (2011). The non-linear effects of life expectancy on economic growth. Economics Letters, 112(1), 116-118. https://doi.org/10.1016/j.econlet.2011.03.027

Ehrlich, I., \& Lui, F. (1991). Intergenerational trade, longevity and economic growth. Journal of Political Economy, 99(5), 1029-1059. https://doi.org/10.1086/261788

Ehrlich, I., \& Yin, Y. (2013). Equilibrium health spending and population aging in a model of endogenous growth: Will the GDP share of health spending keep rising? Journal of Human Capital, 7(4), 411-447. https://doi.org/10.1086/675640

Evans, T. (2018). Building human capital starts with health. The World Bank Blogs. Investing in Health. Retrieved from https://blogs.worldbank.org/health/building-human-capital-starts-health

Friesen, C., Seliske, P., \& Papadopoulos, A. (2016). Using principal component analysis to identify priority neighbourhoods for health services delivery by ranking socioeconomic status. Journal of Public Health Informatics, 8(2), e192. https://doi. org/10.5210/ojphi.v8i2.6733 
Grossman, M. (2000). The human capital model. In A. J. Culyer \& J. P. Newhouse (Eds.), Handbook of Health Economics (Vol. 1, pp. 347-408). The Netherlands: Elsevier Science. https://doi.org/10.1016/S1574-0064(00)80166-3

Gupta, M., \& Barman, T. (2010). Health, infrastructure, environment and endogenous growth. Journal of Macroeconomics, 32 (2), 657-673. https://doi.org/10.1016/j.jmacro.2009.09.001

Hall, R. E., \& Jones, C. I. (2007). The value of life and the rise in health spending. Quarterly Journal of Economics, 122(1), 39-72. https://doi.org/10.1162/qjec.122.1.39

Hansen, C. W. (2013). Life expectancy and human capital: Evidence from international epidemiological transition. Journal of Health Economics, 32(6), 1142-1152. https://doi.org/10.1016/j.jhealeco.2013.09.011

Hansen, C. W., \& Lønstrup, L. (2015). The rise in life expectancy and economic growth in the 20th century. Economic Journal, 125(584), 838-852. https://doi.org/10.1111/ecoj.12261

Heshmati, A. (2001). On the causality between GDP and health care expenditure in augmented Solow growth model. No 423, SSE/EFI Working Paper Series in Economics and Finance, Stockholm School of Economics.

Howitt, P. (2005). Health, human capital, and economic growth: A Schumpeterian perspective. In G. Lopez-Casasnovas, B. Rivera, \& L. Currais (Eds.), Health and economic growth: Findings and policy implications (pp. 19-40). Cambridge, MA: MIT Press.

Jones, C. I. (2016). Life and growth. Journal of Political Economy, 124(2), 539-578. https://doi.org/10.1086/684750

Jones, C. I., \& Klenow, P. (2016). Beyond GDP? Welfare across countries and time. American Economic Review, 106(9), 2426-2457. https://doi.org/10.1257/aer.20110236

Kalemli-Ozcan, S., Ryder, H., \& Weil, D. (2000). Mortality decline, human capital investment, and economic growth. Journal of Development Economics, 62(1), 1-23. https://doi.org/10.1016/S0304-3878(00)00073-0

Kraay, A. C. (2018). Methodology for a World Bank human capital index. The World Bank Policy Research Working Paper8593,.

Kuhn, M., \& Prettner, K. (2016). Growth and welfare effects of health care in knowledge-based economies. Journal of Health Economics, 46, 100-119. https://doi.org/10.1016/j.jhealeco.2016.01.009

Kumar, A., \& Kober, B. (2012). Urbanization, human capital, and cross-country productivity differences. Economics Letters, 117(1), 14-17. https://doi.org/10.1016/j.econlet.2012.04.072

Lenhart, O. (2019). The effects of health shocks on labor market outcomes: Evidence from UK panel data. European Journal of Health Economics, 20(1), 83-98. https://doi.org/10.1007/s10198-018-0985-z

Loichinger, E., \& Weber, D. (2016). Trends in working life expectancy in Europe. Journal of Aging and Health, 28(7), 1194-1213. https://doi.org/10.1177/0898264316656509

Lopez-Casanovas, L., Rivera, B., \& Currais, L. (2005). Introduction: The role health plays in economic growth. In L. Lopez-Cassanovas, B. Rivera, \& L. Currais (Eds.), Health and economic growth: Findings and policy implications (pp. 1-16). Cambridge: MIT Press.

Luca, D. L., Iversen, J. H., Lubet, A. S., Mitgang, E., Onarheim, K. H., Prettner, K., \& Bloom, D. E. (2014). Benefits and costs of the women's health targets for the post-2015 development agenda. Copenhagen Consensus Center Working Paper.

Lucas, R. (1988). On the mechanics of economic development. Journal of Monetary Economics, 22(1), 3-42. https://doi.org/ 10.1016/0304-3932(88)90168-7

Mankiw, N. G., Romer D., Weil D. N. (1992). A Contribution to the Empirics of Economic Growth. The Quarterly Journal of Economics, 107(2), 407-437. https://doi.org/10.2307/2118477

Mas, M., Pérez, F., Uriel, E., Serrano, L., \& Soler, A. (2002a). Capital humano, series 1964-2001. Valencia: Bancaja.

Mas, M., Pérez, F., Uriel, E., Serrano, L., \& Soler, A. (2002b). Metodología para la estimación de las series de capital humano, 1964-2001. Valencia: Bancaja.

Maudos, J., Pastor, J. M., \& Serrano, L. (2003). Human capital in OECD countries: Technical change, efficiency and productivity. International Review of Applied Economics, 17(4), 419-435. https://doi.org/10.1080/0269217032000118756

McDonald, S., \& Roberts, J. (2005). Growth and multiple forms of human capital in an augmented Solow model: A panel data investigation. Economics Letters, 74(2), 271-276. https://doi.org/10.1016/S0165-1765(01)00539-0

Mierau, J., \& Turnovsky, S. (2014). Demography, growth, and inequality. Economic Theory, 55, 29-68. https://doi.org/10. 1007/s00199-013-0749-z

Monterubbianesi, P. (2014). El rol de la salud en el proceso de crecimiento económico: Una revisión de la literatura. Cuadernos de Economía, 33(62), 91-121. https://doi.org/10.15446/cuad.econ.v33n62.43667

Monterubbianesi, P., Grandes, M., \& Dabús, C. (2017). New evidence of the health status and economic growth relationship. Panoeconomicus, Savez Ekonomista Vojvodine, Novi Sad, Serbia, 64(4), 439-459.

Nweze, P. (2015). The impact of health programmes on economic growth. Global Journal of Applied, Management and Social Sciences, 9, 32-43.

Oliva-Moreno, J. (2012). Loss of labour productivity caused by disease and health problems: what is the magnitude of its effect on Spain's Economy? The European Journal of Health Economics, 13(5), 605-614. https://doi.org/10.1007/ s10198-011-0344-9 
O'Mahony, M., \& Samek, L. (2019). The impact of health status on human capital. The Wellness Journal, 3. Global Perspectives

Osag, T., \& Sarkar, J. (2008). Endogenous mortality, human capital and economic growth. Journal of Macroeconomics, 30(4), 1423-1445. https://doi.org/10.1016/j.jmacro.2007.09.002

Pastor, J. M., Peraita, C., Serrano, L., \& Soler, Á. (2018). Higher education institutions, economic growth and GDP per capita in European Union countries. European Planning Studies, 26(8), 1616-1637. https://doi.org/10.1080/09654313.2018. 1480707

Prettner, K., \& Canning, D. (2014). Increasing life expectancy and optimal retirement in general equilibrium. Economic Theory, 56, 191-217. https://doi.org/10.1007/s00199-013-0776-9

Quamrul, H. A., Lester, A., \& Weil, D. (2009). When does improving health raise GDP? In D. Acemoglu, K. Rogoff, \& M. Woodford (Eds.), NBER Macroeconomics Annual 2008 (Vol. 23, pp. 157-204). Cambridge: University of Chicago Press. http://www.nber.org/chapters/c7278

Riley, G. (2012). Economic growth: The role of human \& social capital, Competition \& Innovation. Retrieved from http:// www.tutor2u.net/economics/revisionnotes/a2-macro-economic-growth-capital.html, (Accessed 16 April 2014).

Rivera, B., \& Currais, L. (2004). Public health capital and productivity in the Spanish regions: A dynamic panel data model. World Development, 32(5), 871-885. https://doi.org/10.1016/j.worlddev.2003.11.006

Samek, L., Darko, C., King, W., Sidhu, S. V., Parmar, M., Foliano, F., ... Vassilev, G. (2019). Provision of Human Capital Evidence Review. A Report for the Office for National Statistics, pp. 1-129.

Serrano, L. (1996). Indicadores de capital humano y productividad. Revista de Economía Aplicada, 4(10), 177-190.

Serrano, L., \& Soler, A. (2015). Human capital in Spain and its distribution by provinces (1964-2013). Region, 2(1), R3-R4.

Strauss, J., \& Thomas, D. (1998). Health, nutrition, and economic development. Journal of Economic Literature, 36(2), 766-817.

Strulik, H., Prettner, K., \& Prskawetz, A. (2013). The past and future of knowledge-based growth. Journal of Economic Growth, 18(4), 411-437. https://www.jstor.org/stable/42635332, https://doi.org/10.1007/s10887-013-9098-9

Weil, D. N. (2001). Accounting for the effect of health on economic growth. Brown University, Providence, RI.

Weil, D. N. (2007). Accounting for the effect of health on economic growth. Quarterly Journal of Economics, 122(3), 1265-1306. https://doi.org/10.1162/qjec.122.3.1265

Weil, D. N. (2014). Health and economic growth. In P. Aghion \& S. N. Durlauf (Eds.), Handbook of economic growth (Vol. 2B, pp. 623-682). Amsterdam: Elsevier.

How to cite this article: Gumbau Albert M. The impact of health status and human capital formation on regional performance: Empirical evidence. Pap Reg Sci. 2021;100:123-139. https://doi.org/10.1111/pirs. 12561 
Resumen. El propósito de este documento es analizar el impacto de la salud en el crecimiento, asumiendo que es un componente fundamental del capital humano de una región, junto con la educación. Se utilizan diversas medidas del estado de salud de la población, junto con un índice de salud generado mediante un análisis de componentes principales. Se controló la endogeneidad potencial entre la salud y el crecimiento mediante el uso de regresiones de variables instrumentales y datos de panel dinámicos. Los resultados muestran el efecto positivo en la producción regional de un cambio en el estado de salud y el efecto negativo en el rendimiento regional de las variables sustitutivas de las limitaciones de salud. Esto corrobora la importancia de invertir en la salud junto con la educación, con el objetivo de mejorar no sólo el bienestar de las personas sino también el capital humano y el crecimiento de una región.

抄録: 本稿では、健康が教育とともに地域の人的資本の基本的な構成要素であると仮定し、健康が成長に及ぼす影 響を分析する。集団の健康状態の様々な尺度を、主成分分析によって生成される健康指数とともに使用する。操作 変数回帰と動的パネルデータを用いて、健康と成長の間の潜在的内生性を制御した。結果から、地域アウトプット に対する健康状態の変化のプラスの効果と地域パフォーマンスに対する健康制限の代理変数のマイナスの効果が示 される。これは、個人の福祉だけでなく、地域の人的資本と成長を改善することを目的として、教育とともに健康 にも投資することの重要性を裏付けている。 